\title{
Themed Section New Approaches to the Bioarchaeology of Roman Britain - ERRATUM
}

\author{
By REBECCA GOWLAND
}

https://doi.org/10.1017/S0068113X18000296 Published online by Cambridge University Press, 20 April 2017.

It has been brought to our attention that two Britannia articles by Rebecca Gowland were inadvertently published online as a single piece sharing the same Digital Object Identifier (DOI).

We have corrected this error by separating the two pieces and assigning a new unique DOI to the introduction, namely, https://doi.org/10.1017/S0068113X18000296, while 'Embodied Identities in Roman Britain: A Bioarchaeological Approach' will retain the existing DOI: https://doi.org/10. 1017/S0068113X17000125

We apologise to the author and to readers who have been affected in their navigation to the respective articles.

\section{BIBLIOGRAPHY}

Gowland, R. (2017). Themed Section New Approaches to the Bioarchaeology of Roman Britain. Britannia, 48, 175-177. doi:10.1017/S0068113X18000296

Gowland, R. (2017). Embodied Identities in Roman Britain: A Bioarchaeological Approach. Britannia, 48, 177-194. doi:10.1017/S0068113X17000125 